\title{
article
}

\section{Rethinking the travel of ideas: policy translation in the water sector}

\author{
Farhad Mukhtarov, Biotechnology and Society Group, Department of \\ Biotechnology, Delft University of Technology, the Netherlands \\ f.mukhtarov@tudelft.nl \\ Environmental Policy Analysis, Institute for Environmental Studies, \\ Vrije Universiteit Amsterdam, the Netherlands \\ f.mukhtarov@vu.nl
}

\begin{abstract}
The travel of policy ideas across countries is a widely acknowledged phenomenon. Conventional approaches to the study of this process hinge on concepts such as 'policy transfer', 'policy diffusion', 'lesson-drawing' and 'institutional isomorphism'. These approaches are influential in understanding public policy; however, they assume perfect rationality of actors, the stability of governance scales and the immutability of policy ideas in their travel. I propose policy translation as a new approach to counter these shortcomings and study the travel of policy ideas in order to shed light on pertaining policy questions, such as whether the travel of policy ideas may be navigated, and if so, how. I illustrate the relevance and value of policy translation with a case study from the water sector in Turkey.
\end{abstract}

key words policy translation $\cdot$ policy transfer $\cdot$ contingency $\cdot$ scale $\cdot$ meaning

\section{Introduction}

The travel of policy ideas across countries and political systems is very common. Policies in as diverse areas as the protection of women's rights, economic liberalisation, sustainability and education have spread around the world in the last half century (Dobbin et al, 2007). Such prominence in public policy has inspired much scholarly work. While the use of particular terms by particular disciplines is not exclusive, political scientists have attempted to explain the travel of ideas in terms of 'policy transfer', 'policy diffusion' and 'lesson-drawing' (eg, Dolowitz and Marsh, 1996; Evans, 2009; Marsh and Sharman, 2009). Planners and geographers have discussed the travel of ideas in terms of 'institutional transplantation' (eg, De Jong et al, 2002) and more recently 'policy mobility' (McCann and Ward, 2011) and 'policy mutation' (Peck and Theodore, 2012). Sociologists have examined the questions of 'diffusion' of agricultural innovations across rural communities (eg, Rogers, 2003).

However, in spite of the ubiquity of travel of policy ideas and the abundance of studies within diverse disciplines, little is known about what makes certain policies spread widely while others remain limited in mobility. It remains a mystery why some policy ideas produce impact on the ground as they travel across countries while 
others are formally adopted but rarely produce policy change. Most importantly, scholars have not critically discussed the very possibility of navigating the process of travel of ideas. Conventional approaches to the travel of ideas proved unable to answer these questions and have been widely criticised for the assumptions that actors who engage in the process of the travel of ideas act rationally (eg, Freeman, 2009), that the meanings of policy ideas are unaltered in the process of travel (eg, Mukhtarov, 2009) and that this process is linear and stage-based (eg, Lendvai and Stubbs, 2009). Work in several disciplines within social sciences is being undertaken to advance alternatives to conventional approaches to the travel of ideas. With this paper, I intend to review the conventional approaches and their critiques, and offer a new approach of policy translation.

Policy translation takes an agency approach with an explicit attention to policy actors in the process of the travel of ideas. Approaching policy analysis from the translation angle means asking the question of who participated in multiple translations of ideas across sites and networks, how this process took place and to what effect. Most importantly, translation traces how the distinctions between what conventional approaches call 'global', 'national', 'regional' and 'local' become blurred; how the shape and the very meaning of introduced ideas change to a considerable extent; and how contingent the policy process is in terms of its outcomes. Policy translation offers an analytical framework to guide scholars in understanding how policy agents engage with the categories of meaning, scale and contingency in the travel of ideas in order to advance their position in policy making. By going beyond formulaic and linear models of policy transfer and diffusion, and by defining what is important to study in the process of the travel of ideas, policy translation contributes to the theory of public policy and advances new avenues for future research. The case study in this article, in turn, illustrates the empirical value of the framework vis-à-vis conventional approaches to the travel of ideas.

This article is organised in a number of sections. The next section provides a detailed account of existing scholarship on the travel of ideas. The following section positions policy translation in the public policy and related literatures. Then, the value of policy translation is discussed as illustrated by a case study. The final section summarises the argument of the article and suggests possible trajectories for the development of the approach in the future.

\section{Rethinking the travel of ideas}

\section{Conventional approaches to the study of the travel of ideas}

The literature gives various labels to the process whereby innovations, policies and ideas cross spatial or organisational borders:

- 'imitation, emulation and innovation' (Westney, 1987);

- 'institutional transplantation' (De Jong et al, 2002);

- 'lesson-drawing' (Robertson, 1991; Rose, 1993);

- 'institutional transfer' (Jacoby, 2001);

- 'policy transfer' (Dolowitz and Marsh, 1996; Evans and Davies, 1999; Stone, 2004);

- 'policy mobility' and 'policy mutation' (Cook and Ward, 2012; McCann and Ward, 2012; Peck and Theodore, 2012). 


\section{Rethinking the travel of ideas}

The terms the authors use define the subtle differences between these approaches. 'Diffusion' may presume privileging institutions over the freedom of policy actors and 'transfer' may presume the immutability of what is being 'transferred'. In order to avoid such presumptions, I refer to this process as the 'travel of ideas'. The metaphor 'travel' entails neither a coercive, nor a voluntary, nor a negotiation-based character of this process and has no normative connotations. By 'idea', I refer to parts of policies, as defined by Dolowitz and Marsh (1996), as 'policy goals, structure and content; policy instruments and administrative techniques; institutions; ideology; ideas, attitudes and concepts; and negative lessons'.

A growing number of parallel literatures that deal with the travel of ideas present a challenge of both heterogeneity and conceptual overstretching of policy transfer (James and Lodge, 2003; Benson and Jordan, 2011). Conventional approaches differ in contending what is being moved, what boundaries are being crossed and how this process happens. Stone $(2000,2001,2004)$ has further argued that 'policy transfer' must account for the 'soft' transfer of ideas, norms and knowledge (Stone, 2004: 546). In political science and public policy studies, the policy transfer literature has expanded to include debates on globalisation, Europeanisation and multi-level governance (Radaelli, 2000). In critical geography and the literature on the social construction of scale, terms such as 'policy mobility' (McCann and Ward, 2012) and 'policy mutation' (Peck and Theodore, 2012) are used to capture the processes of the spread of global ideas to localities (Marston, 2000; Smith, 2000; Neumann, 2008).

Policy transfer scholarship focuses primarily on actors and the process by which policies and practices travel, as well as on transfer agents (Dolowitz and Marsh, 1996; Evans and Davies, 1999; Stone, 2000, 2004). This literature has asked a number of questions:

- Why engage in policy transfer?

- Who transfers policy?

- What elements of policy are transferred?

- Are there different degrees of transfer?

- From where are policies transferred?

- What factors enable or constrain policy transfer?

Dolowitz and Marsh (1996) introduced a continuum of types of policy transfer that includes voluntary, coercive and negotiated forms of transfer. Policy diffusion scholarship, in turn, sees the travel of ideas as a function of structural forces, such as industrialisation, globalisation and regionalisation, rather than the work of free agents (Tews, 2005; Brinks and Coppedge, 2006). This stream of literature focuses on wider societal patterns rather than the process of policy making, and often includes quantitative studies (Tews, 2009). A more normative stand is adopted by the lessondrawing approach (Rose, 1993, 2001, 2005), which focuses on understanding the conditions under which policies or practices operate in exporter jurisdictions and assumes that ideas can be 'imported' voluntarily by policy makers. It develops guidelines to implement successful lesson-drawing. It has, however, attracted criticism for being apolitical (eg, De Jong, 2009).Yet another approach, institutional isomorphism, attempts to explain the drive of organisations to become homogenous in an organisational field through the forces of uncertainty and emulation, norm diffusions via professionals and competition (DiMaggio and Powell, 1983, 1991). 
According to Benson and Jordan (2011), since the end the 1990s, policy transfer has developed into a popular model to study policy processes. As Dolowitz (2009) mentioned in a special issue of this journal, policy transfer has made a valuable contribution to public policy. The conceptual frameworks have been advanced to study the travel of ideas, its mechanisms have been exposed, and the set of criteria on how to judge the success and failure of policy transfer has been suggested. Overall, the policy transfer literature has examined the extent of freedom that states enjoy in setting their own agendas and policy development. Evans (2009) has further suggested the value of policy transfer in developing multi-level explanations of policy development, and in engaging various bodies of literature in explaining policy developments. The engagement with global civil society (Stone, 2004, 2010), multi-level governance (Evans and Davies, 1999; Evans, 2005) and policy networks (Stone, 2004; Evans, 2005) has contributed to broadening the scope of policy transfer. However, there is a longstanding criticism of policy transfer and related approaches, engagement with which may be beneficial for advancing our tools for understanding this complex process.

\section{Shortcomings of conventional approaches}

The policy transfer literature has assumed perfect rationality of actors in executing the transfer (James and Lodge, 2003; Evans, 2009), has not distinguished itself clearly from other forms of policy making and policy change, and has underplayed the power of ideas in policy making. Scholars of policy transfer, such as Dolowitz and Marsh (1996), have noted that policy transfer suffered from too much positivism and too little engagement with constructivism - a criticism that is still valid (Benson and Jordan, 2011). More recent writing on policy transfer attempts to respond to this criticism by suggesting a focus on 'soft transfer' and norm brokerage (Stone, 2004, 2010), multi-level governance (Evans, 2009) and policy learning (Dolowitz, 2009). However, the shortcomings of policy transfer and other conventional approaches are fundamentally in the assumptions that they make about policy actors engaged in the travel of ideas, and the process of the travel of ideas.

The criticism of policy transfer may be summarised in terms of three areas. First, the policy transfer literature does not engage sufficiently with constructivist ideas. Dolowitz and Marsh (1996), in their early review of the concept, noted its mostly positivist nature and limited engagement with the ideas of the social construction of problems and solutions. According to an increasing number of scholars, much scope exists for studying the travel of ideas in interpretive terms (Freeman, 2009; Lendvai and Stubbs, 2009; Abdelal et al, 2010; Benson and Jordan, 2011). This especially concerns the assumed stability of the meaning of policy ideas in the process of their travel. Modification of meaning and multiple interpretations of policy ideas in various contexts remain largely unaddressed.

Second, the policy transfer literature continues to make the assumption of the rationality of agents and deliberation in the process of engaging in policy transfer. The role of contingency in this process remains largely unaddressed (Freeman, 2009; Lendvai and Stubbs, 2009). Duncan (2009: 456), herself a former policy maker, suggests that in practice, policy transfer is often 'unsystematic' and 'uncoordinated', and the transfer is more about the 'policy triggers', or ideas that inspire development of a policy in a certain direction. Contingency is more than the unintended outcomes of 
planning in policy. The travel of ideas is an inherently contingent process as concepts such as 'sustainability', 'evidence-based policy' and 'precautionary principle' will trigger as they travel an idiosyncratic and context-specific chain of policy events that is impossible to predict and control.As Jasanoff (1998: 85) claimed, '[k]nowledge claims and artifacts not only are contingent upon particular ways of seeing and knowing, upon culture and history, but also are capable of imparting a misleading veneer of homogeneity to disparate understandings of nature, artifacts, and society'. It is in this misleading homogeneity, and in the assumptions of deliberate process of predicting and controlling, where conventional approaches fall short.

Third and finally, the policy transfer literature has not engaged with the literature on the politics of scale (Marston, 2000). While multi-level approaches were developed to study policy transfer (Evans and Davies, 1999; Evans, 2005, 2009), Lendvai and Stubbs $(2007,2009)$ have pointed to the importance of politics of scale and iterative links between the global, national and local processes in the production of space. I follow Lebel et al (2008: 129) who define the politics of scale as 'situations whereby actors, directly or indirectly, attempt to shift the levels of study, assessment, deliberation and decision-making authority to the level and scale which most suits them, that is, where they can exercise power more effectively'.

While the important contribution of policy transfer and conventional approaches to the travel of ideas must be acknowledged, important shortcomings they bear suggest a need for fundamentally new approaches to emerge to overcome them. Such an approach needs to be based on the issues where conventional approaches fall short and may benefit from the greater engagement with ideational approaches, embracing the politics of scale, and studying language as a tool for political struggle.

\section{Policy translation to study the travel of ideas}

Policy translation is rapidly emerging as an alternative to conventional approaches (eg, Freeman, 2009; Lendvai and Stubbs, 2009). The term 'translation' originally came from linguistics, has built upon the research in multiple disciplines since the 1970s and acquired its distinctive place in public policy relatively recently with the process of conceptual development that is currently ongoing (Carlile, 2004; Yanow, 2004; Lendvai and Stubbs, 2007; Clarke, 2008; Freeman, 2009).

The evolution of the concept of 'translation' proceeded from the focus on the micro level and the process of communication between actors in the policy process (Latour, 1986), to the meso level - interaction in an organisation (Czarniawska and Sevon, 1996) - and on to the macro level of the spread of ideas across countries and jurisdictions (Freeman, 2009; Lendvai and Stubbs, 2009). Thus, for sociologists of science, translation is 'the spread in time or place of anything - claims, artefacts, goods....' (Latour, 1986: 267). For scholars of organisational studies, translation is an iterative process by which ideas are materialised, turned into slogans, objects or actions in practice and then turned again into ideas as they are communicated. For recent theorists of translation in public policy, the central research question is to understand the effect of language and meaning in politics (Ivekovic, 2005; Newman, 2006; Lendvai and Stubbs, 2007, 2009; Clarke, 2008; Freeman, 2009). Lendvai and Stubbs (2007: 15) suggested the following distinction between policy transfer and policy translation: 
[The] policy transfer process should be seen as one of continuous transformation, negotiation, and enactment on the one hand, and as a politically infused process of dislocation and displacement ('unfit to fit'), on the other hand.... [Policy translation] suggests the need to pay greater attention to the ways in which policies and their schemes, content, technologies and instruments are constantly changing according to sites, meanings and agencies.

There is an important difference between policy transfer and translation. Policy translation can be defined as the process of modification of policy ideas and creation of new meanings and designs in the process of the cross-jurisdictional travel of policy ideas. Translation allows viewing the 'global' in 'local', and 'local' in 'global', with regard to the adoption, implementation and travel of ideas, and enables simultaneous consideration of ideas, objects and interests (Latour, 1986; Fadeeva, 2004; Lendvai and Stubbs, 2009). I advocate for a narrow use of policy translation to focus on key policy actors in their struggle to engage with the travel of ideas across countries or political jurisdictions by framing, reframing and modifying the meaning of ideas that travel; engaging in constructing problems and solutions as pertinent to certain scales.

Having emerged as a response to the insensitivities and failures of conventional approaches to the travel of ideas, policy translation is grounded on three major tenets. First, it leaves behind the assumptions of rationality, linearity of the policy process and the very possibility of the 'transferability' of policies. The term 'transferability', commonly used in the literature on policy transfer and lesson-drawing (eg, Rose, 1993; Benson et al, 2012), assumes that it is the quality of a policy to be more or less amenable to transfer. Policy translation, in turn, suggests that the process of the travel of policy ideas is affected by complex interactions of multiple factors, and characteristics of policy ideas taken in an abstract sense provide little help in judging possible outcomes of the travel.

Second, the meaning of policy ideas and problems that such ideas are called upon to solve inevitably change in the process of travel. Discourses, ideologies, symbols and identities provide some examples of factors that influence the process of ideational transformation.

Third and finally, scale loses its fixed geographical content. Policy translation discards the notions of local, regional, national and global as given, and claims that actors engage in the social and political construction of problems and solutions as pertinent to a particular scale, in a tradition of the social construction of scale (Marston, 2000).

Policy translation is necessarily an actor-based approach, as ideas do not travel by themselves, nor are they pushed around by forces such as regionalisation, neoliberalism or globalisation. Policy actors, experts, states and non-state actors, as well as organised and non-organised citizens, play an important role in translation. Thus, a policy translation analysis starts with discerning important policy coalitions and investigating how policy actors, individually or in groups, engage in an argumentative struggle in shaping meanings and constructing scale, and how contingency of the travel of ideas and the process of embedding, dis-embedding and re-embedding these ideas from the context influence such struggle and its outcomes. Essentially, this framework is valid to a study of policy change in general. However, with the travel of ideas the stability of meaning of ideas, scale and the assumption of intentionality and rationality of actors are more common. 


\section{Rethinking the travel of ideas}

Policy translation is akin to a social constructivist approach to the travel of ideas. This is manifested, for example, in the emphasis on the social construction of scale (Marston, 2000; Neumann, 2008). By examining the meaning that actors attach to 'local', 'regional', 'national' and 'global', and by analysing the material effects that such ordering produces, the scale becomes an important analytical category (Marston, 2000). Here, insights from anthropology are useful, in which 'locality is not everywhere, not for every purpose, the same thing; sometimes it is a family, sometimes a town, a nation, sometimes a flow or a field...' (Comaroff and Comaroff, 1999: 294). How this 'locality' is constructed, therefore, is the subject of investigation.

In addition to scale, studying the role of ideas, discourses, non-material symbols and norms in shaping identities and interests of actors is integral to policy translation. That said, however, policy translators are not devoid of agency in structuring the meaning of ideas, constructing scale and manipulating the process within the limits of the possible. Another constructivist manifestation of policy translation is in its emphasis on the role of language as a medium that allows an analyst to establish what discursive positions actors take, and based on that, what their identity is (Epstein, 2010).

The parallel literature on critical geography has also engaged with the critique of conventional approaches. The strength of geography in the study of the travel of ideas is its traditional focus on the importance of space and scale in how policies are made (Prince, 2010). By embracing the notion of the social and political production of scale (Cook and Ward, 2011, 2012), such studies contribute to studying the travel of ideas. Urbanism studies currently build on the notion of 'policy transfer as assemblage' to present the process of the development of cities as assembling 'parts of elsewhere' in a politically contested and multi-scalar process of policy making (Marston, 2000; Prince, 2010; Cook and Ward, 2011, 2012; McCann and Ward, 2011, 2012). This literature emphasises the importance of experts in the travel of ideas (Cook and Ward, 2011, 2012), as well as infrastructure that enables the travel of ideas, such as international conferences (Cook and Ward, 2012). There is much that policy translation can learn from the critical geography literature, especially with regard to its treatment of the politics of scale, and employment of assemblages (Prince, 2010; Peck and Theodore, 2012). This research is also very useful for methodologies for the study of the travel of ideas, such as 'mobile methods' (McCann and Ward, 2012) and the 'distended case approach' (Wedel, 2005; Peck and Theodore, 2012).

Despite many similarities and potential for learning, policy translation differs from 'policy mobilities' in a number of ways. First, assemblages are prominent in the geography literature, yet these are not synonymous with policy translation as the issues of the discursive construction of meaning and the inherent contingency of policy are not explicitly dealt through assemblages approaches. Second, the geography literature is close to the literature on policy networks and the role of experts and expertise in the travel of ideas. The role of other actors, as well as unorganised citizens, in translation is left unarticulated. Third, and most importantly, many authors in the geography tradition still use the conceptual apparatus of policy transfer, although attempting to restructure it with a stronger emphasis on non-state actors and the use of ethnographies as a research method (Prince, 2010; Cook and Ward, 2011, 2012; McCann and Ward,2011,2012).A good example is the reference made in this literature to the importance of characteristics of policies that travel: '[Alt]hough there are all manner of contingencies along the way, the movement of policy is nonetheless shaped and sharpened by certain pathways and trajectories that make some policies more 
likely to travel...." (Cook and Ward, 2012: 139). Policy translation takes a stronger stand on the role of contingency and claims that the attributes of a policy play little, if any, role in how likely it is to travel.

Table 1 presents the main differences between policy transfer and policy translation, structured along some of the main questions that Dolowitz and Marsh (1996) asked in their seminal review of the field.

\section{Table 1: Comparison of policy transfer and policy translation approaches}

$\begin{array}{ll}\text { Approaches } & \text { Policy transfer } \\ \text { Who transfers/translates? } & \begin{array}{l}\text { Initially only government } \\ \text { officials and policy elites; later } \\ \text { broadened to include non-state } \\ \text { actors }\end{array}\end{array}$

What is transferred/translated?

\section{How does transfer/translation} happen?

What enables and constrains transfer/translation?

Rationale for analysis

\section{Mechanistic and linear, with prescriptive guidelines}

Characteristics of a policy idea, path-dependency, ideology of the country where the policy idea is introduced, bureaucracy, size and efficiency

Instrumental: looking for a 'fit' between a policy and the context
Policy translation

All types of actors engaged in policy making; tailored to study informal networks that pervade levels of governance

Policies, institutions, ideas; the notion of 'transferability' is rejected as the outcome of this process cannot be reduced to only qualities of the policy at hand

Highly contingent; no guidelines are available

Constraints and opportunities for translation are socially and politically constructed and are meaningful only in the context

'Unfit to fit': looking to understand how policy ideas are translated to construct a temporary 'fit'

An important issue is the development of a methodological apparatus to study policy translation. One answer may come from the emerging field of the anthropology of policy. As Wedel et al (2005: 34) put it, the anthropology of policy is the 'cultural and philosophical underpinnings of policy - its enabling discourses, mobilising metaphors, and underlying ideologies and uses'. As the geography literature claims, critical ethnographies, and the extended case study method, therefore, may shed light on the fluidity of policy translation (McCann and Ward, 2012; Peck and Theodore, 2012). On the other hand, traditionally ideational structures and norms in the policy process have been traced through the use of language as 'policy is made in words' (Freeman, 2009: 431).Alongside ethnographies and anthropological concepts, discourse analysis is well equipped to discern the identities and values systems of actors judging by their take on certain discursively contested issues.

Figure 1 depicts the essence of policy translation as an approach taking into consideration the fluidity of scale as in 'scale destabilisation', transformation of the meaning of ideas as in 'meaning destabilisation', and the contingency of the policy process as in 'increased contingency'. 
Figure 1: Policy translation and categories of meaning, scale and contingency

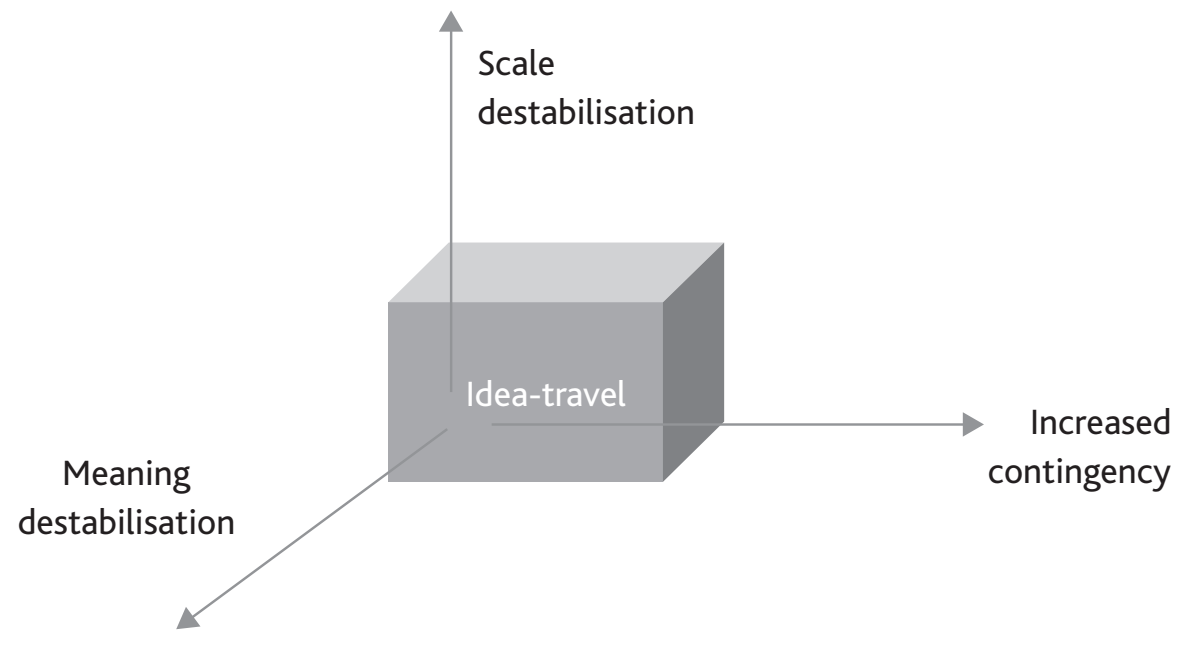

To summarise, in this section I have introduced policy translation as a distinct approach to the study of the travel of ideas, which draws attention to the issues of policy contingency, scale and modification of meaning. I have discussed the origins of the concept, its major differences from conventional approaches to the travel of ideas and similarities and distinctions with parallel literatures of critical geography and the social construction of scale. In the next section I discuss policy translation in the domain of water policy in South-Eastern Turkey.

\section{Policy translation and the making of water policy in South-Eastern Turkey}

\section{Globalisation of water governance and policy translation}

Water policy is an excellent realm to study policy translation. The experiences of countries with regard to water policy are being collected and disseminated by supranational actors, such as UN-Water, the European Union, the World Bank, the United Nations Development Programme (UNDP), as well as international networks such as the Global Water Partnership, the World Water Council and the International Network of Basin Organizations. As a result, approaches to water such as integrated water resources management (IWRM) and river basin organisations, to name two, have travelled around the world and can be found in dozens, if not hundreds, of countries (Conca, 2006; Mukhtarov, 2007, 2008; Molle, 2008; Mukhtarov and Gerlak, 2012). Thus, it is not surprising that scholars of water governance have researched the travel of ideas with regard to:

- the international spread of IWRM (Mukhtarov, 2007, 2009);

- transboundary water governance (Gerlak, 2007);

- water allocation (Swainson and de Loe, 2011):

- river basin planning in Turkey (Hermans, 2011);

- participatory catchment management (Benson et al, 2012). 
However, most of these studies have relied on conceptual frameworks, tools and terms of policy transfer and lesson-drawing. For example, Hermans (2011) synthesised policy transfer and lesson-drawing approaches to produce a four-stage model of policy transfer; whereas Swainson and de Loe (2011) and Benson et al (2012: 46), in line with Rose (1993: 118), refer to the 'transferability' of policy ideas, agreeing that abstract characteristics of policy ideas matter for their travel. There is little discussion of contingency, meaning and scale in the travel of policy ideas in these studies. The case study below illustrates the value of looking at these three categories of policy translation.

\section{Policy translation of regional development administration in South-Eastern Turkey}

The South-Eastern Anatolia Project (abbreviated as GAP in Turkish: Güneydogu Anadolu Projesi), a massive water and land development project, was launched in the early 1980s to eradicate poverty in the region (Nippon-Koei and Yüksel Joint Venture, 1989; Ünver, 1997, 2001). My main research question was to understand how a global policy idea of a 'regional development administration' (RDA) had been translated into the context of Turkey in the period 1989-2009 (Nippon-Koei and Yüksel Joint Venture, 1989; GAP-RDA and UNDP, 1997). The GAP project is an excellent opportunity to study the travel of policy ideas as the idea of setting up an administration to manage the project has come from an international consortium of consultants in the spirit of then popular regionalism in natural resources management. I used qualitative methods during my fieldwork, which took place in March 2007 and August and September 2008, with an internship at the GAP Regional Development Administration (GAP-RDA) in Ankara and field trips to the regional office in Sanliurfa. Overall, I conducted 29 interviews and kept a field journal, which were augmented by official documents, conference papers, dissertations, articles and reports for the data analysis.

The GAP-RDA was established in 1989, following a Master Plan prepared by a consortium of the leading Japanese engineering consultancy Nippon Koei Co. Ltd. and its Turkish counterpart Yüksel Proje A.S. (GAP-RDA, 2002). The idea to create a regional development administration, the only one in Turkey at the time, was inspired by the examples of regional development in the Tennessee Valley Authority and the Lower Colorado River Authority in the United States (1998-99; GAP-RDA, 2000). However, differently from those two prototype organisations, GAP-RDA had not been given authority over planning and implementation of public works in the region. Rather, it had been bestowed with the mandate to coordinate water, land, energy and socioeconomic development in the region (Ünver, 2001).

Since its inception, the GAP-RDA had faced reluctance to cooperate from the major water and planning bureaucracies in Turkey (GAP-RDA, 2004). The increasing international prominence of the GAP-RDA and its narrative of 'sustainable human development' had further heightened the tensions with other public organizations as to who 'owned' the project. With the change of the government in Turkey in 2002 and a subsequent shift in the political patronage of the GAP-RDA, the majority of the management personnel left the organization. Citing the need for the GAP-RDA to work closely with the agencies in the region, the government first stated the intention to shut the offices of the GAP-RDA in Ankara and transfer the employees to Sanliurfa 
in early 2009 (Sanliurfa Gazette, 2009). At present, the GAP-RDA's functions are reduced to monitoring and reporting to the government on the progress towards completion of the project by 2012; a role strikingly less significant than had been envisioned for it in the early 1990s.

\section{Policy translation: destabilisation of scale}

The issue of scalar politics is at the heart of the demise of GAP-RDA: the international discourse and fundraising activity of GAP-RDA contributed to its demise nationally. This may be called scalar 'overspill' - when activity at one scale has serious implications for another scale of governance. It demonstrates the interconnectedness of scales if not the very fragility of the boundaries between what we call 'regional', 'national' and 'global' scales. Policy translation, with its attention to the fluidity of scale, therefore, helps in understanding how the 'oxymoron' of GAP-RDA at its creation, the inherent contradictions between the central and the regional in Turkey and the power struggle between GAP-RDA and State Hydraulic Works (abbreviated in Turkish as DSI) resulted in its demise.

Olcay Ünver, a former longstanding president of GAP-RDA had been a key player in the project. From its inception, GAP-RDA had triggered institutional competition with two other major players in Turkey's water domain: the State Planning Organization (SPO), which allocates funding and approves all plans for public spending, and DSI, which is the major state agency dealing with water issues in Turkey. In 2007, GAP-RDA had a budget of about US\$7 million compared to DSI's US $\$ 30$ billion (Zahir Erkan, 2007, personal communication). Deprived of financial resources to operate its own projects in the region, and having little political power to coordinate DSI and SPO, GAP-RDA had come under the constant pressure to justify its existence.

Having sensed little potential at the national level, Ünver and his team took the discursive resonance to the international level (Öktem, 2005). Ünver became a member of the World Water Council (WWC), the Global Water Partnership (GWP), the International Hydrological Association (IHA), the International Water Resources Association (IWRA), the Tokyo Club and the board of the International Journal of Water Resources Development. As a result, Ünver and his team had succeeded in obtaining international prestige for the project, earning the project the International Water Resources Association's Millennium Award for sustainability (GAP-RDA and UNDP, 2002).

However, the strategy of mobilising international funding and support had further alienated GAP-RDA from DSI at the national level, which perceived the project as its own, and the activities of GAP-RDA at the international level as competition. With the international rise of GAP-RDA and of awareness about the project globally, came its stagnation in Turkey. The strongest blow came in 2003 when the newly elected government changed the leadership of the administration resulting, from my observations, in most of its English-speaking staff leaving. Eventually, the headquarters in Ankara closed in 2009 and GAP-RDA's responsibilities were reduced to monitoring the project from its regional office in Sanliurfa (Sanliurfa Gazette, 2009). 


\section{Policy translation: destabilisation of meaning}

As stated above, policy translation puts an emphasis on modification of the meaning of a policy idea according to sites, times, negotiation and struggles. GAP-RDA had been conceived as a coordinating agency for comprehensive regional planning, turned into a 'discourse-generator' and a fundraising agency.

By launching a comprehensive publication and promotion policy (Altinbiler 2004, Erhan 1997; Ünver 1997), with regular reports published in Turkish and English, and providing research opportunities for visiting researchers and UNDP evaluators, it set the terms by which this project could be conceptualized, analyzed and criticized. (Öktem, 2005: 247)

An element of discourse-generation was closely linked to fundraising as sustainable human development needed to be demonstrated in practice. GAP-RDA needed its own small-scale projects in order to claim that sustainability was not only the rhetoric but also practice. Such practice came from the projects within the GAP-RDA/UNDP programme on sustainable human development: CATOMs (The Multi-Purpose Women Support Centres), GIDEMs (a project on entrepreneur support) in GAP, Rehabilitation of Children Working on the Streets and some other projects. The project of resettlement of Halfeti for the Birecik Dam construction (completed in 2000) was an example of participative resettlement, which must be welcomed and encouraged. However small and insignificant at the scale of South-Eastern Anatolia, these projects helped GAP-RDA in establishing its discourse and image as a discoursegenerator and a successful fundraiser (Öktem, 2005; ÜSIAD, 2008). These changes in the 'identity' of GAP-RDA were the results of intentional and concerted action of the leadership of the organisations. Yet, they are indicative of the inevitable modification of policy ideas in a certain context due to cultural, historic and political reasons, and therefore, inherent contingencies of the policy process.

\section{Policy translation: the effect of contingency}

Finally, policy translation called attention to the effects of contingencies in the policy process after the establishment of GAP-RDA. The scalar politics with the emergent strategies of Ünver and the ensuing changes in the identity and activities of GAPRDA are indicative of the impossibility of 'controlling and predicting' and the inherent contingency and context-dependence of any policy ideas and policy processes. Policy moves, and unintended changes, are not accidental side-effects of otherwise rational and pre-planned transfer, but an essential and inseparable part of it (Freeman, 2009). Three development plans were drawn up for the GAP project:

- the Master Plan of 1989;

- the Regional Development Plan of 2002, drawn up by Ünver to justify the existence of GAP-RDA but never implemented due to the changes in the political government (Guven, 2008, personal communication);

- the new consolidated GAP Action Plan of 2007, which prioritised the fast completion of the project (Yaman, 2008, personal communication). 
Such speed with which plans were changed, the unintended and unforeseen changes in the organisational identity of GAP-RDA and the new government's decision to close the headquarters of the administration in Ankara, all suggest the inevitability of the unintended, unforeseen and contingent way in which policy ideas travelled. The differences between what was planned and what happened in reality were reflected in the evaluation report by the Turkish civil society organisation, ÜSIAD (2008:167): '[A]ccording to the law, the public agencies that have budget with regard to the GAP region, must direct their projects to the GAP-RDA for the necessary amendments, and only then are the documents sent for approval to the SPO. However, all of this is different in practice.' Such deviation of practice from intention is common in GAP, as well as in development and planning projects in general. The way in which GAPRDA came to be is, therefore, not merely a contingency aspect of policy making, it is translation in action, as well as what policy translation studies.

\section{Conclusions}

This article has made a two-fold contribution. First, it has reviewed and summarised the heterogeneous literature on the travel of policy ideas, it has advanced policy translation as a novel approach in public policy and it has defined the criteria by which it is distinguished from other approaches in social sciences and public policy. Second, it has illustrated how attention to three categories of policy translation may be useful in explaining the process and outcomes of how a policy idea fares in a new political context.

The major added value of policy translation is in providing a heuristic to study the travel of ideas by drawing attention to its three categories of scale, meaning and contingency. Thus, policy translation does not answer the question: How do policy ideas travel? Instead, it answers the question: How to study the travel of ideas? I believe that with further analytical, methodological and empirical work along the lines of policy translation, scholars will answer the first question, too. Policy translation pays explicit attention to policy actors and focuses on:

- how they engage in morphing and transforming ideas coming from elsewhere;

- how they choose to act at a particular geographical scale;

- to what extent contingencies of politics and context intervene with intentions of policy actors.

It goes beyond the attention to 'why to transfer' and how 'transferable' policy ideas are. Instead, policy translation shows the fluidity, emergence and complexity of the policy process involving the use of ideas from elsewhere. The case of the SouthEastern Anatolia Administration (GAP-RDA) in Turkey has illustrated the value of this approach.All three categories featured in the political process and, taken together, provided an explanation of the emergence, operation and the demise of GAP-RDA.

There is much scope for further development of policy translation, which needs to advance in at least three major directions. First, analytical tools should be devised to study the three categories of policy translation. Perhaps, cross-fertilisation with the fields of political geography and anthropology of policy may be useful in this regard. Second, the theoretical developments need to explore the interface of policy translation with other theories and concepts in public policy, such as policy learning, 
policy change and, more generally, the tradition of social constructivism. Within this exploration, methodologies developed in discourse analysis and interpretive policy analysis could prove useful. Finally, the third avenue for future research includes the development of hypotheses that could guide translation research towards more explanatory models of how the engagement of competing policy actors with scale, meaning and contingency impacts on the policy process.

\section{Acknowledgements}

I am very grateful to Helen Ingram, Andrea Gerlak, Robin Pierce, Dave Huitema, Paul Stubbs, Constanze Haug, Richard Freeman and an anonymous reviewer for comments on earlier versions of this article. Funding for the field research came from the Central European University, Open Society Institute.

\section{References}

Abdelal, R., Blyth, M. and Parsons, C. (eds) (2010) Constructing the international economy, Ithaca, NY and London: Cornell University Press.

Altinbiler, D. (2004) 'Development and management of the Euphrates-Tigris basin', Water Resources Development, 20 (1): 15-33.

Benson, D. and Jordan, A. (2011) 'What we learnt from policy transfer research? Dolowitz and Marsh revisited', Political Studies Review, 9 (3): 366-78.

Benson, D., Jordan, A. and Huitema, D. (2012) 'Involving the public in catchment management: an analysis of the scope for learning lessons from abroad', Environmental Policy and Governance, 22: 42-54.

Brinks, D. and Coppedge, M. (2006) 'Diffusion is no illusion: neighbour emulation in the third wave of democracy', Comparative Political Studies, 39 (4): 463-89.

Carlile, P. (2004) 'Transferring, translating, and transforming: an integrative framework for managing knowledge across boundaries', Organizational Science, 15 (5): 555-68.

Clarke, J. (2008) 'Reconstructing nation, state and welfare: the transformation of welfare states', in M. Seeleib-Kaiser (ed) Welfare state transformations: Comparative perspectives, Basingstoke: Palgrave Macmillan.

Comaroff,J. and Comaroff,J. (1999) 'Occult economies and the violence of abstraction: notes from the South African postcolony', American Ethnologist, 26 (2): 279-303.

Conca, K. (2006) Governing water: Contentious transnational politics and global institution building, Cambridge, MA: MIT Press.

Cook, I. and Ward, K. (2011) 'Trans-urban networks of learning, mega events and policy tourism: the case of Manchester's Commonwealth and Olympic Games projects', Urban Studies, 48 (12): 2519-35.

Cook, I. and Ward, K. (2012) 'Conferences, informational infrastructures, mobile policies: the process of getting Sweden 'BID ready', European Urban and Regional Studies, 19 (2): 137-152.

Czarniawska, B. and Sevón, G. (1996) Translating organizational change, Berlin and New York, NY: Walter de Gruyter.

De Jong, M. (2009) 'Rose's “10 steps”: why process messiness, history and culture are not vague and banal', Policy \& Politics, 37 (1): 145-50.

De Jong, M., Lalenis, K. and Virginie, M. (2002) The theory and practice of institutional transplantation: Experiences with the transfer of policy institutions, Dordrecht: Kluwer Academic Publishers. 


\section{Rethinking the travel of ideas}

DiMaggio, P. and Powell,W. (1983) 'The Iron Cage revisited:institutional isomorphism and collective rationality in organizational fields', American Sociological Review, 48 (2): 147-60.

DiMaggio, P. and Powell, W. (1991) The new institutionalism in organizational analysis, Chicago, IL: University of Chicago Press.

Dobbin, F., Simmons, B. and Geoffrey, G. (2007) 'The global diffusion of public policies: social construction, coercion, competition, or learning', Annual Review of Sociology, 33: 449-72.

Dolowitz, D. (2000) 'Learning from abroad: the role of policy transfer in contemporary policy-making', Governance: An International Journal of Policy and Administration, 13 (1): 5-24.

Dolowitz, D. (2009) 'Learning by observing: surveying the international arena', Policy \& Politics, 37 (3): 317-34.

Dolowitz, D. and Marsh, D. (1996) 'Who learns what from whom? A review of the policy transfer literature', Political Studies, 44 (2): 343-57.

Duncan, S. (2009) 'Policy transfer: theory, rhetoric and reality', Policy \& Politics, 37 (3): 453-8.

Epstein, C. (2010) 'Who speaks? Discourse, the subject and the study of identity in international politics', European Journal of International Relations, 17 (2): 327-50.

Erhan, S. (1997) 'The social structure in the GAP region and its evolution', Water Resources Development, 13 (4): 505-22.

Evans, M. (2005) Policy transfer in global perspective, Aldershot: Ashgate.

Evans, M. (2009) 'Policy transfer in critical perspective', Policy Studies, 30 (3):243-68.

Evans, M. and Davies, J. (1999) 'Understanding policy transfer: a multi-level, multidisciplinary perspective', Public Administration Review, 77 (2): 361-85.

Fadeeva, Z. (2004) 'Translation of sustainability ideas in tourism networks: some roles of cross-sectoral networks in change towards sustainable development', Journal of Cleaner Production, 13: 175-89.

Freeman, R. (2009) 'What is “translation”?', Evidence \& Policy, 5 (4): 429-47.

GAP-RDA and UNDP (1997) GAP Sustainable Development Programme, Ankara, Turkey: GAP-RDA and UNDP.

GAP-RDA (2000) Workshop on American experiences in water-based development, GAP-RDA, Ankara, Turkey, GAP-RDA.

GAP-RDA (2002) GAP Regional Development Plan: Executive summary, Ankara, Turkey. GAP-RDA.

GAP-RDA (2004) SWOT Analysis of the GAP Regional Development Administration, Ankara, Turkey: GAP-RDA.

Gerlak, A. (2007) 'Lesson learning and trans-boundary water: a look at the Global Environment Facility's international water program', Water Policy, 9: 55-72.

Hermans, L. (2011) 'An approach to support learning from international experience with water policy', Water Resources Management, 25: 373-93.

Ivekovic, R. (2005) 'Transborder translatin', Eurozine Magazine, www.erozine.com Jacoby,W. (2001) 'The imitation-innovation trade-off: does "borrowing dull the edge of husbandry"?', Comparative Political Studies, 34 (3): 263-93.

James, O. and Lodge, M. (2003) 'The limitations of "policy transfer" and "lesson drawing” for public policy research', Political Studies Review, 1 (2): 179-93. 
Jasanoff, S. (1998) 'Contingent knowledge: implications for implementation and compliance', in W. Weiss and H. Jacobsen (eds) Engaging countries: Strengthening compliance with international environmental accords, Cambridge, MA: MIT Press.

Latour, B. (1986) 'The powers of association', in J. Law (ed) Power, action and belief: A new sociology of knowledge, London: Routledge.

Lebel, L., Daniel, R., Badenoch, N., Garden, P. and Imamura, M. (2008) ‘A multi-level perspective on conserving with communities: experience from upper tributary watersheds in montane mainland Southeast Asia', International Journal of Commons, 2 (1): $127-54$.

Lendvai, N. and Stubbs, P. (2007) 'Policies as translation: situating trans-national social policies', in S. Hodgson and Z. Irving (eds) Policy reconsidered: Meaning, politics and practices, Bristol: The Policy Press, http://paulstubbs.pbworks.com/f/ LendvaiStubbsPolicyTranslation.pdf

Lendvai, N. and Stubbs, P. (2009) 'Assemblages, translation, and intermediaries in South East Europe', European Societies, 11 (5): 673-95.

McCann, E. and Ward, K. (eds) (2011) Mobile urbanism: Cities and policymaking in the global age, Minneapolis, MN and London: University of Minnesota Press.

McCann, E. and Ward, K. (2012) 'Assembling urbanism: following policies and "studying through" the sites and situations of policy making', Environment and Planning A, 44 (1): 42-51.

Marsh, D. and Sharman, J.C. (2009) 'Policy diffusion and policy transfer', Political Studies, 30 (3): 269-88.

Marston, S. (2000) 'The social construction of scale', Progress in Human Geography, 24 (2): 219-42.

Molle, F. (2008) 'Nirvana concepts, narratives and policy models: insights from the water sector', Water Alternatives, 1 (1): 23-40.

Mukhtarov, F. (2007) 'Integrated water resources management from a policy transfer perspective', in International Congress on River Basin Management: Proceedings, Antalya, Turkey: State Hydraulic Works of Turkey and World Water Council.

Mukhtarov, F. (2008) 'Intellectual history and current status of integrated water resources management: a global perspective', in C. Pahl-Wostl, P. Kabat and J. Möltgen (eds) Adaptive and integrated water management: Coping with complexity and uncertainty, Berlin: Springer Berlin Heidelberg.

Mukhtarov, F. (2009) 'The hegemony of integrated water resources management: a study of policy translation in England, Turkey and Kazakhstan', doctoral thesis, Department of Environmental Sciences and Policy, Central European University, Budapest, Hungary.

Mukhtarov, F. and Gerlak, A. (2012) 'The global rise of river basin organizations discourse: exploring actors and strategies', Global Governance.

Neumann, R. (2008) 'Political ecology: theorizing scale', Progress in Human Geography, 33 (3): 398-406.

Newman, J. (2006) 'Constituting trans-national governance: spaces, actors and vocabularies of power', paper presented to the stream 'Trans-national social policy' at the 4th ESPAnet Conference, Bremen, September.

Nippon-Koei and Yüksel Joint Venture (1989) GAP Master Plan, Ankara, Turkey: GAP-RDA. 


\section{Rethinking the travel of ideas}

Öktem, K. (2005) 'Reconstructing the geographies of nationalism: nation, space and discourse in twentieth century Turkey', Doctor of Philosophy thesis, University of Oxford.

Peck, J. and Theodore, N. (2012) 'Follow the policy: a distended case approach', Environment and Planning A, 44:21-30.

Prince, R. (2010) 'Policy transfer as policy assemblage: making policy for creative industries in New Zealand', Environment and Planning A, 42: 169-86.

Radaelli, C. (2000) 'Policy transfer in the EU: institutional isomorphism as a source of legitimacy', Governance: An International Journal of Policy Administration and Institutions, 13 (1): 25-43

Robertson, D. (1991) 'Political conflict and lesson-drawing', Journal of Public Policy, 11 (1): 55-78.

Rogers, E.( 2003) Diffusion of innovation, New York, NY: Free Press.

Rose, R. (1993) Lesson-drawing in public policy: A guide to learning across time and space, Chatham, NJ: Chatham House.

Rose, R. (2001) Ten steps in learning lessons from abroad, Working Paper, Swindon: Economic and Social Research Council.

Rose, R. (2005) Learning from comparative public policy: A practical guide, London: Routledge.

Sanliurfa Gazette (2009) The transfer of GAP-RDA to Urfa has been confirmed, http:// www.sanliurfa.com/news_detail.php?id=6993

Smith, N. (2000). 'Scale', in Johnson, R., Gregory, D., Pratt, G. and Watts, M. (eds) The dictionary of human geography, Blackwell: Oxford.

Stone, D. (2000) 'Non-governmental policy transfer: the strategies of independent policy institutes', Governance: An International Journal of Policy and Administration, 13 (1): 45-62.

Stone, D. (2001) Learning lessons, policy transfer and the international diffusion of policy ideas, Warwick: Centre for the Study of Globalization and Regionalization, University of Warwick, http://poli.haifa.ac.il/ levi/res/stone-2000.pdf

Stone, D. (2004) 'Transfer agents and the global networks in the "transnationalization" of policy', Journal of European Public Policy, 11 (3): 545-66.

Stone, D. (2010) 'Private philanthropy or policy transfer? The transnational norms of the Open Society Institute', Policy \& Politics, 38(2): 269-87.

Swainson, R. and de Loe, R. (2011) 'The importance of context in relation to policy transfer: a case study of environmental water allocation in Australia', Environmental Policy and Governance, 21 (1): 58-69.

Tews, K. (2005) 'The diffusion of environmental policy innovations: cornerstones of an analytical framework', European Environment, 15 (2): 63-79.

Tews, K. (2009) 'From law taking to policy making: the environmental dimension of the EU accession process - challenges, risks and chances for the SEE countries', Environmental Policy and Governance, 19 (2): 130-9.

Time Magazine (1998-99) Visions of Europe, Winter 1998-1999, special issue, Time Inc. Ünver, O. (1997) 'South-Eastern Anatolia Integrated Development Integrated Development Programme', Water Resources Development, 13 (2): 187-207.

Ünver, O. (2001) 'Institutionalizing the sustainable development approach: coordination across traditional boundaries', Water Resources Development, 17: 511-20.

ÜSIAD (2008) The GAP report: What happened in GAP! Economic, strategic and political developments in the region, Istanbul, Turkey: ÜSIAD. 
Wedel, J., Shore, C., Feldman, G. and Lathrop, S. (2005) 'Towards an anthropology of public policy', Annals of the American Academy of Political and Social Science, 600:30-51. Westney, E. (1987) Imitation and innovation:The transfer of Western organizational patterns to Meiji Japan, Cambridge, MA: Harvard University Press.

Yanow, D. (2004) 'Translating local knowledge at organizational peripheries', British Journal of Management, 15 (S1): 9-25. 